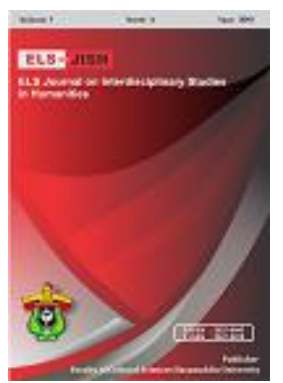

ELS-JISH

ELS Journal on Interdisciplinary Studies on Humanities

Volume 1 Issue 3, 2018

ISSN (print) : 2621-0843

ISSN (online) : 2621-0835

Homepage : http://journal.unhas.ac.id/index.php/jish

\title{
Erotic Narration of Syair Lebai Guntur
}

\author{
Mustari $^{1}$ \\ mustariacok@gmail.com
}

\begin{abstract}
The text of Syair Lebay Guntur contained in the Syair Lebay Guntur text by Raja Ali Haji records the traces of the 'disgraceful' behavior of some Malay people in the past who practiced "Cina Buta" marriages. It is aiming to find muhallil or a proponent to reconcile a couple (wife and husband) who had divorced by triple divorce. Because the problem raised in the poetry is a matter of muhallil, inevitably, its diction appears to be erotic in every verses of the poetry. This study employed the theory of diction and language style with stylistic analysis of Malay to uncover two raised problems they are (1) Can erotic diction contained in SLG be categorized as vulgar pornography? (2) How to interpret the erotic diction? The findings show that the erotic diction in Syair Lebai Guntur poem cannot be categorized as pornography diction, but it rather as a diction adapted to the poem's theme of the practice of "Cina Buta" marriage. The diction considered as an allusion that is intended as teaching values which is not need to be copied by anyone to avoid a disgrace.
\end{abstract}

Keywords: Erotic Diction, Syair Lebai Guntur, Syair Suluh Pegawai text, Raja Ali Haji.

How to cite: Mustari. (2018). Erotic Naration of Syair Lebai Guntur. ELS Journal on Interdisciplinary Studies in Humanities, 1(3), 309-.320

\section{Introduction}

Language is the most important and influential element in a literary work such as poetry, drama, short stories, and novels. Mat (2004) stated that literature is nothing but a social phenomenon that uses language as a container. Language itself is a social creation. Mana (1988) noted that language in a creative work is not only an important tool in conveying stories, but also a medium to convey the ideas and thoughts of the author. With languages, the stories, ideas, and thoughts can be accepted by the reader. Language is a medium of literature. According to Rahman (2017:156) literature stimulates the sensitivity of its readers. It presents various aspects of life and even constantly parses life, or may be, a reflection on life.

Shahnon (1979) confirmed that a novelist needs media, among others: rhythm, tone and colour to give a real atmosphere and background in his work, but all that can only be created through language. Therefore, the issue of selection, compilation, repetitions of words, formation and sequence of a sentence, figurative words and all the intricacies of the use of language is very important. Therefore, language will give strength to the theme, setting, character, plot, perspective and approach of the author. Besides that, according to Hasan (1986) that language can also provide an

\footnotetext{
${ }^{1}$ UIN Sunan Kalijaga Yogyakarta
} 
overview of the atmosphere: psychological, sociological, trustworthy, economic, political, philosophical and satirical in a literary work.

The use of language styles in each work will be very different from one author to another. This is due to differences in educational background, experience, genre, interests, expertise and so on. In this case the Raja Ali Haji (RAH) is not an exception. He was known as a humanist and Malay language expert in the past. He was a skilful author especially in using and choosing the language style to convey his ideas in every works he created. One of his works that became the raised spotlight in this study is Syair Lebay Guntur (SLG). RAH has succeeded in portraying the filmic language style and its genius about the bad behaviour of some Malays who practice the "Cina Buta" marriage in their day, perhaps even now. It is interesting to be discussed in order to test the erotic language style of RAH which is also known as a cleric and Islamic religious advisor for the rulers in the Malay Kingdom cantered on Pulau Penyengat in the 19th century AD.

SLG is actually the insertion chapter in Syair Suluh Pegawai (SSP). The SSP manuscript contains the teachings of marriage according to Islamic law and Malay customs. RAH inserted the SLG chapter which tells about the practice of "China Buta" marriage in the Malay-Islamic community. Who is Lebai Gutur? Lebai Gutur is a fictional character that can be referred to everyone in Malay-Islamic community at that time. SLG is contained in a long manuscript entitled Fa Hâzâ Inilah Syair yang Dinamai akan Dia Suluh Pegawai, in a collection of manuscripts named Inilah Syair Siti Shiyânah Shâhibah al-'Ulum wa al-Amânah, Riau, Pulau Penyengat, Indrasakati, Kampung Tengah, $1333 \mathrm{H}$. it is a works of Al-Marhum Al-Maghfur Lahu Raja Haji Ali Ibnu Al-Marhum Raja Haji Ahmad Ibnu Al-Marhum Al-Ghâzî Raja Haji Yang Dipertuan Muda Riau asy-Syâhid fî Sabîlillâh Qaddasallâhu Asrârahum wa Ja'ala AlJinân Matswâhum, who is none other The famous RAH.

\section{Methodology}

In outlining this study, the writer fully used the principles of qualitative research. Qualitative analysis will produce findings that are not easy to be interpreted hence its analysis doesn't use the convenience of statistical procedures like Quantitative anlysis that usually use certain formulas. The validity of qualitative analysis is entirely determined by the ability of researcher himself to capture, to understand, and to describe the phenomena around the object of the study.

In qualitative research, new problems will usually emerge after passing direct observation. This is where the foresight and clarity of the mind of the researcher needed. Qualitative researchers believe that the best way to understand a phenomenon is to observe it, read it, and protect it, in its context. Qualitative researchers will try to uncover a person's experience with natural social phenomena. Because the object of this study is poetic text, therefore, the analysis was done qualitatively thorough content analysis by involving phenomena in the text that involve RAH and his ideas contained in the text of SLG.

\section{SLG Main Themes and "Cina Buta" Marriage History}

It is easy to know that the main theme of this satire verse is the "Cina Buta" ("Blind Chinese") marriage practice in the Islamic-Malay community. The theme is found in the 5th verse of the 32nd article which reads: Fadhilat ini sudahlah nyata// sebab pekerjaan bercina buta// mengikutkan hawa nafsu yang meta// jadilah beroleh nama yang lata//. 
Mustari. 1(3): 309 - 320

The disgraceful behaviour of "Cina Buta" is the main subject of the RAH satire in the verses of the Poem. In the treasures of Islamic teachings, "Cina Buta" obtained its hypogram on muhllil behaviour. Muhllil comes from the Arabic language which the lexical means to find a proponent for married couples who have divorced three divorces. In the Quran (Al-Baqarah [2]: 230) Allah says:

And if he has divorced her [for the third time], then she is not lawful to him afterward until [after] she marries a husband other than him. And if he [i.e., the latter husband] divorces her [or dies], there is no blame upon them [i.e., the woman and her former husband] for returning to each other if they think that they can keep [within] the limits of AllOEh. These are the limits of AllOEh, which He makes clear to a people who know [i.e., understand]. (Saheeh International, 1997).

Searching for muhllil or the proponent is prohibited by the Prophet Muhammad. The Prophet sallallaahu 'alaihi wa sallam cursed muhllil and al muhallal lahu "(Narrated by Abu Daud No. 2076 and Ibn Majah No. 1934. Shaykh al-Albani said that this hadith is valid). The deprivation of Prophet Muhammad SAW against the practice of muhllil because it is actually a rhetorical marriage to outsmart Q.S. alBaqarah [2]: 230. A legal marriage according to the above verse is not by looking for muhllil. The marriage of the widow triple divorce must take place naturally. Then, the divorce also takes place naturally. After that, the first halal husband can marry his third wife, but what is wrong is sometimes there is a triple divorce which is done in a hurry and causes regret. As a result, seeking muhllil was taken with "presumption" it is already valid according to Islamic law. This rhetoric marriage is called "Cina Buta" in Malay culture. The essence of "Cina Buta" behavior is the intercourse committed by Muhilillil with his wife. This refers to the events of Sahabat at the time of the Prophet Muhammad SAW.

It was reported to us from Abu Bakr bin Abu Syaibah and Amar and Naqid Amr from Sufyan from az-Zuhri from Urwah from Ayesha saying: "Rifa'ah's wife once came to the Messenger of Allah and said: I was a wife of Rifa'ah and I was, and the divorce to me was three times, then I married Abdurrahman Ibn Zubair, but unfortunately he was like the tip of a cloth that is impotence, then Prophet Muhammad SAW smiled and said: Do you want to return to Rifa'ah? Oh, no, before you really feel the little honey of Abdurrahman bin Zubair (intercourse) and he also feels your little honey."(HR. Muslim).

Starting from the understanding of the hadith above, without sexual activity the people involved in this disgraceful behavior consider the marriage of "blind China" not yet legal, and the muhllil may not divorce his "wife". This is the highlight of SLG, and to illustrate that behavior, RAH uses erotic narratives. If it is associated with the diction of RAH choices in SLG, then erotic diction means meaningful word choice and language style that leads to sexual behavior from the mood, physical preparation, make out, core work, to the physical and environmental consequences and psychological consequences of the "Cina Buta" core work.

The history of the behavior of the disgraceful marriage of "Cina Buta" is certainly very advanced in years, perhaps as old as the acceptance of Islam among the Malays. In addition to the "Cina Buta" marriage, Hamka called another term, namely "Chindor buta" marriage. However, this term is less popular than the term "Cina Buta". 
Once upon a time there was a couple who had a fight because the matter was trivial. At the height of the fight, the wife shrill,

"Divorce me. I am willing!".

Hearing the scream, the husband who was also at the peak of anger, answered, no less emotional,

"Do you really want it, damn female?"

"Divorce me!", Replied his wife in a rising voice.

"Good, I divorce you, triple divorce", said her husband.

The marriage of the husband and wife ended with thalaq ba'in kubra which should not be reconciled except with the conditions stated in the Q.S. al-Baqarah [2]: 230. Shortly thereafter, regret arose between the two because they still loved each other. Furthermore, they already had children who were dependent on their legal marriage. What else they can say, they want to refer immediately, but they can't, while waiting for the requirements of Q.S. al-Baqarah [2]: 230 are too long and almost impossible. Then "Cina Buta" is the one that they looking for.

Initially, this practice began with finding a mu'allaf Chinese who did not understand the teachings of Islam as a whole. He was called "Cina Buta" because he was considered to be blind to the teachings of Islam, especially about marriage and divorce. The term "Cina Buta" can also be referred to the type of Malay children's play, "Lu Blind Chinese Lu". The Chinese mu'allaf was given a wage to marry the widow and to have sex with her. Then he asked to divorce her again so that her exhusband could reconcile to his ex-wife after the 'iddah' had passed. In some cases, it turns out that the Mu'allaf China is not blind and does not want to be fooled. After the marriage, he did not want to divorce his wife, but the wife also did not want to be divorced. Blast the hopes of her ex-husband.

In its development, to anticipate the "Cina Buta" who are not blind, not the mu'alaf Chinese who are given wages, but "inert" males to replace the mu'allaf Chinese. Because of "inert", of course he could not think sane and only followed the directors' directions. Usually these "inert" men were indeed "nurtured" with special tasks that were always ready to be "Cina Buta" whenever needed. A "pleasant" task, and to facilitate the "things" business, a special room is provided next to the mosque or langgar.

The "Cina Buta" begins with marriage, then the "Cina Buta" couple is herded into a special room to carry out the next task. The most awaits answer after they leave is, "have they had intercourse?" This answer is important and determines whether or not the husband reconcile to his widow. If the answer is "already", then the "Cina Buta" is asked to recite the divorce to his "wife". The "Cina Buta" task is done. The widow is just waiting for 'iddah (a waiting period of 3 months and 10 days for a widow arranged in Islam before she is allowed to remarry) to reconcile with her first husband.

\section{Questioning Erotic Diction in SLG}

Because the core activity in the practice of "Cina Buta" marriage is sexual intercourse, then inevitable, the diction used always leads to fellowship activities. This is where RAH shows his ability in choosing diction and style of language. If he wasn't careful, he would be trapped in vulgar words and porn. 


\subsection{Three-Point Problem}

The main characters in this SLG story are Haji Dermawan and Encik Jurita. Haji Dermawan was a person who acted as "Cina Buta" while Encik Jurita was the widow who got triple divorce. Helpers: (1) Lebai Guntur is Encik Jurita's husband, (2) Lebai Abu is the person who reads prayers when "Cina Buta" marriages happen, (3) Si Laba is the owner of a rick hut on the edge of the city where the plays of "Cina Buta" take place, (4) Si Kembang is the wife of si Laba, (5) The unnamed villager, a bitch who been the cause of the triple divorce.

\begin{abstract}
Inillah tuan satu cerita
zaman dahulu empunya warta seorang lebai khabarnya nyata parasnya elok bagai dipéta
\end{abstract}

Cantik isteri lebai nan tuan cahaya durjanya kilau-kilauan memberi hati bimbang dan rawan sukar bandingnya di bawah awan

\section{Akan tetapi Lebai nan tuan sangatlah suka bermain perempuan beberapa sundal diperbuat lawan balik ke rumah jaranglah tuan}

Dia ada seorang isteri
elok tidak lagi terperi
putih bersih durja berseri
lakunya lepas duduk berdiri
Namanya tuan Encik Jurita
lidahnya petah pandai berkata
siapa terpandang jatuhlah hatinya
mabuk birahi semata-mata
Di dalam hal demikian peri
lalu diketahui oleh isteri
Jurita pun marah tidak terperi
mintak thalaq diri sendiri

Dia ada seorang isteri elok tidak lagi terperi putih bersih durja berseri

Namanya tuan Encik Jurita lidahnya petah pandai berkata siapa terpandang jatuhlah hatinya

Di dalam hal demikian peri

lalu diketahui oleh isteri mintak thalaq diri sendiri

The happy life of the handsome husbands, Lebai Guntur, with the beautiful Encik Jurita was damaged because of Lebai Guntur hobbies to prostitute. The meaning of the word "sundal" according to the KBBI (Compete Indonesian Dictionary) is: (1) bad behaviour (about women who are bad behaviour), (2) bitch, prostitutes. The words are: prostitution, prostitution and prostitution. Whatever the lexical meaning, it is generally understood that women who carry "sundal" predicate are women who are willing to have sex with married couples, both paid and free. RAH chooses "sundal" diction because it is commonly known in the Malay community, even in various ethnic groups and ethnic groups in the archipelago.

\subsection{Looking for Muhallil}

Based on the original idea, there were several "Cina Buta" marriage models that had been practiced. There are times when the idea is belonging to the first husband, but sometimes the widow who designs the suggestion, and there are times when those "Cina Buta" candidates offer their services (Mustari, 2018). In the SLG case, the idea came from Encik Jurita (the triple widow). So there was a conspiracy between all parties involved.

Jurita pun kesal tidak terperi

kerana memintak thalaqnya diri

sebab rupanya elok berseri

disangkanya Lebai tiada memberi

Lebai pun berjalan dengan segera hatinya susah tidak terkira terkenang Jurita intinya mutiara parasnya elok tiada bertara

\section{Jurita berkata merawan-rawan berjalanlah Kekanda muda rupawan segeralah cari muhallil dermawan supaya boleh kembali tuan}

Berjalan sambil sebak di dada menuju ke rumah Haji yang muda wang enam ringgit di tangannya ada akan pengupah mensetubuh adinda 
Kerana Haji sahabatnya nyata

dari kecil sudahlah beserta

sampai beristeri akan Jurita

masih bersahabat bersetuju kata

At the beginning of the story, RAH uses the word muhllil. This word is familiar to clerics who understand the issue of marriage in the teachings of Islam. This is religious language style that has the meaning of seeking "halal" even though "not lawful" in order to "allow" the first husband to remarry the widow of three. What worse is the widow obliged to have sex with other men who are paid. In the SLG case, it costs $\$ 6.00$ (six ringgit) to make copulation. Certainly, it is not cheap wages in those days.

\subsection{Transactions and Selection of Cina Buta" Places}

Lebai berkata merawan-rawan Ayuhai Adinda Haji Dermawan sampaikan hajat kekanda nan tuan menjadi muahallil adinda perempuan

\section{Adapun Haji muda terbilang sudah melihat parasnya gemilang Jurita nan elok bukan kepalang Haji mendengar lemahlah tulang}

\section{Berkata lagi Haji yang muda} janganlah walang wahai Kekanda pasal muhallil sudilah ada boleh khabarkan kepada adinda Sebab pekerjaan kekanda jua meskipun hilang dengannya jiwa setelah putus muwafakatnya kedua di rumah Si Laba kita bersua
Haji mendengar hatinya suka tetapi tidak terupa di muka jawabnya apa perintahnya Kaka sekaliannya hamba kerja belaka

\begin{abstract}
Teranglah ia akan Jurita parasnya elok mengerun dinta putih bersih laksana pita cantik manis petah berkata
\end{abstract}

Sekedar pekerjaan demikian itu tiadalah hamba mengelak di situ jika zakar lemah sukutu dengan telunjuk adinda bantu Jika di rumah kekanda dahulu pekerjaan kita terbuka malu sebab orang datang selalu siang dan malam bertalu-talu

In the transaction between Lebai Guntur and Haji Dermawan, it was seen how happy Haji Dermawan who would get a "windfall". The image of having sex immediately with Encik Jurita is illustrated in RAH word choice, Jurita nan elok bukan kepalang// Haji mendengar lemahlah tulang.

The core work of this "Cina Buta" is intercourse. It is well understood by Haji Dermawa. Then the transaction is locked by the sentence, Sekedar pekerjaan demikian itu// tiadalah hamba mengelak di situ// Jika zakar lemah sekutu// dengan telunjuk adinda bantu. Intercourse in Islam is the penetration of the penis into the vagina,it is not justified other objects besides the penis that is inserted into the vagina. So, it is strange when $\mathrm{RAH}$ chooses the diction, dengan telunjuk adinda bantu. This is a style of language that exaggerates to reinforce a purpose that I understand as a strong desire of Hajj Generous to play "Cina Buta". This purpose is strengthened by Haji Dermawan sentence, Sebab pekerjaan kekanda jua// meskipun hilang dengannya jiwa. The "Cina Buta" candidate is willing to lose his soul for the "pleasent" task. No half-hearted, the short transaction of the muhallil was closed with choosing the location to do "Cina Buta" which is in Si Laba's hut on the countryside, so the activity was unknown to the crowd. Jika di rumah kekanda dahulu// pekerjaan kita terbuka malu// sebab orang datang selalu// siang dan malam bertalu-talu.

\subsection{Marriage without 'Iddah and Preparation for doing "Cina Buta"}


Menegangkan segala aurat anggota telur setengah masak dimakan serta nikahlah ia dengan Jurita di rumah Si Laba di balik kota
Doa dibaca Lebainya Abu

habis doa lalu berjamu

Haji pun hendak masuk kelambu

dengan Jurita akan bercumbu

Sangat bersiap Haji yang muda senjata yang tajam sedialah ada berdegab-degab rasanya dada kerana hendak masuk melanda

The "Cina Buta" work seems to have to run efficiently and as briefly as possible. Without 'iddah, the marriage of tahlil (legalization marriage) was immediately carried out in Si Laba's hut by inviting Lebai Abu to recite the festive prayer after the marriage (at the same time as a marriage cognoscente?). Before marriage, Haji Dermawan consumes half-cooked eggs. Apparently, the efficacy of half-cooked kampong chicken eggs has long been believed to be able to strengthen the muscles of the penis when having sex. Without wasting any time, Haji Dermawan wants to do his job to have sex with Encik Jurita. Doa dibaca Lebainya Abu// habis doa lalu berjamu// Haji pun hendak masuk kelambu// dengan Jurita akan bercumbu//.

In describing the desire of the Haji Dermawan passion and the preparation of his "Cina Buta" sex activities, RAH describe it as a battle. The "penis" diction was replaced with "sharp weapons", while the "copulation" diction was replaced with "entered". Sangat bersiap Haji yang muda/l senjata yang tajam sedialah ada// berdegab-degab rasanya dada// kerana hendak masuk melanda/l.

Encik Jurita yang baik rupa tubuhnya putih lagipun shofa dengan Haji akan berjumpa hatinya seperti digoncang gempa

Bahu-bahuan pula digosokkan tubuh dan kaki semua disapukan harumnya tidak dapat diperikan sirih sekapur pula dimakan
Mandilah ia bersuci diri berbedak berlulur lengan dan jari muka yang cantik makin berseri seperti Jurita sukar dicari

\section{Hajipun masuk ke dalam bilek kedua matanya sangatlah celek muka Jurita lalu ditelek dilihatnya sungguh Jurita nan molek}

Not losing to Haji Dermawan, Encik Jurita as the side who will be "dicina butai" does not lose his sexual desire for Haji Dermawan. It can be seen from the preparations that are described by RAH carefully. Like the preparations for a new bride with a legitimate husband, it is what Encik Jurita did in welcoming her "Cina Buta" sex activities. Dengan Haji akan berjumpa// hatinya seperti digoncang gempa//. Lalu diikuti dengan mandilah ia bersuci diri// berbedak berlulur lengan dan jari// muka yang cantik makin berseri// seperti Jurita sukar dicari//. Kemudian, Bahu-bahuan pula digosokkan// tubuh dan kaki semua disapukan// harumnya tidak dapat diperikan// sirih sekapur pula dimakan//.

The choice of RAH diction is bringing my thoughts to the past. Eating betel-lime leaves to scent bad breath is only done by old women, not now. Physical preparation and atmosphere preparation before having sex that was done by Encik Jurita and Haji Generous indeed was in accordance with the guidance of sexual relations in Islam, but all of that is only valid in a marriage which is also valid according to Syara'.

\subsection{Core Activities of "Becina Buta"}


ISSN: (E) 2621-0835, (P) 2621-0843

Pukul sembilan Hajipun menuwai memasukkan cincin ke jari suwai rumah Si Laba bergoncang berbuwai lantai dan dinding berderik berderai

\section{Di tengah halaman dia terdiri} sambil memandang kanan dan kiri (tiada siapa yang ia cari) hanyalah rumahnya bergoncang sendiri

\section{Diambilnya tali lalu memanjat} di pangkal alang ia mengikat rumahnya sudah condong ke barat puncanya di pangkal niur ditambat
Si Laba pun tangah makan tenggayun

dirasanya rumah sangat berhayun disangkanya gempa balak yang turun dari atas rumahnya ianya terjun

Si Laba berpikir seorang-orang Haji keparat terlalu garang akhirnya runtuh rumahku karang baiknya aku beri temberang

Not waiting for a long time, at 9:00 pm the "Cina Buta" sex activity started to play. The choice of RAH is "menuwai", like harvesting rice in the harvest season. Pukul sembilan Hajipun menuwail/. The activity was marked by the shaking and creaking of the floor and wall of Si Laba's hut, rumah Si Laba bergoncang berbuwai// lantai dan dinding berderik berderai//. RAH chooses a beautiful diction than a vulgar one in describing the intercourse activity. The sentence that is chosen is memasukkan cincin ke jari suwai. "Cincin" diction is a substitute for "vagina" and "Jari" as the substitute of "penis", while the "suwai" diction describes a fit, right, not loose and not narrow.

Apparently the "Cina Buta" sex was so powerful that Si Laba felt like an earthquake was struck. After plunging from his house, he realized the only one that shakes was the hut. To save the rickety hut that was already inclined westward, he tied it with a temberang rope (Temberang rope is the rigging used to confirm the mast of the screen) at the base of a coconut tree. He also swore at Haji Deramwan, Haji keparat terlalu garang// akhirnya runtuh rumahku karang// baiknya aku beri temberang//.

\subsection{Legitimate Sex}

Kemudian naik pula ke rumah syahwatnya berang tiadalah lemah isteri sendiri lalu dijamah geramnya seperti hendak dimamah

Adapun Si Laba empunya isteri yaitu Si Kembang putih berseri parasnya elok sukar dicari perbuatanya Haji semua didengari

Setelah sampai hajat keduanya baharulah puas rasa hatinya kepada tempayan bersuci dirinya keduanya pun masuk ke tempat tidurnya
Si Laba nan sangat bangkit inginnya mendengar Si Haji melakukan hajatnya jadilah Si Laba datang nafsunya tiadalah dapat lagi ditahannya

Si Laba pun birahi bukan kepalang akal pikirnya lenyap dan hilang dijamahnya Si Kembang paras gemilang akan melipurkan dendam dan walang 
Mustari. 1(3): 309 - 320

The "Cina Buta" activities of Haji Dermawan and Encik Jurita who were very noisy in the room were heard out by the owner of the house. . Si Laba nan sangat bangkit inginnya// mendengar Si Haji melakukan hajatnyal/ jadilah Si Laba datang nafsunya// tiadalah dapat lagi ditahannya/. Then he came to the wife, Si Kembang. RAH chooses the diction "dijamah". Kemudian naik pula ke rumah// syahwatnya berang tiadalah lemah// isteri sendiri lalu dijamah// geramnya seperti hendak dimamah//. Si Laba pun birahi bukan kepalang// akal pikirnya lenyap dan hilang// dijamahnya Si Kembang paras gemilang// akan melipurkan dendam dan walang//. Sex between Si Laba and Si Kembang is certainly legal because they are legitimate husband and wife.

\subsection{Advanced Play and Consequences}

\section{Kemudian keduanya menidurkan diri waktupun hampir dini hari Haji pun bangun menjima' isteri bergoncanglah rumah tidak terperi}

Rumah itu runtuhlah sudah perbuatan Haji yang "haram zadah" Haji pun diam tundak tengadah pura-pura tiada ianya endah

Bini Si Laba datang berlari memeluk Si Laba sambil berperi hendaknya sabar kiranya diri Haji pun sudah dipeluk isteri

\section{Lebai Guntur datang berlari berseluwar bulat ia berdiri orang pun tertawa kanan dan kiri malunya Lebai tidak terperi}

Apabila sudah siangnya hari Haji pun bermohon kepada isteri berpeluk bercium tiada terperi berpaling ke belakang thalaqnya diberi
Haji pun tengah di dalam dharurat rumahnya putus tali pendarat robohlah rumah ke pihak barat Si Laba pun bangun mengata, "Keparat!"

Si Laba pun sangat hatinya geram mencabut golok lalu menerkam Haji pun mencabut badik yang tajam keduanya sama hendak bertikam

Jadilah gempar sekalian orang sebab perbuatan Haji yang garang ada tertawa ada memberang pekerjaan yang sulit jadilah terang

Fadhilat ini sudahlah nyata sebab pekerjaan bercina buta mengikutkan hawa nafsu yang meta jadilah beroleh nama yang lata

Apabila sudah lepas 'iddahnya Lebai pun balik kepada isterinya dibaharui nikah oleh walinya harang terconteng atas mukanya

Actually for legal, "Cina Buta" sex is enough to be done once. But, apparently, the "Cina Buta" couple did not want to let go the opportunity to pass by. Then the second round is held in the early morning. Kemudian keduanya menidurkan diri// waktupun hampir dini hari// Haji pun bangun menjima' isteri//. The "Jima" diction was the same as the diction of intercourse in Islamic religious terms which indicated that $\mathrm{RAH}$ was indeed an expert in Islam.

But the result of the second round was so severe. Bergoncanglah rumah tidak terperi//. Haji pun tengah di dalam dharurat// rumahnya putus tali pendarat// robohlah rumah ke pihak barat// Si Laba pun bangun mengata, "Keparat!"//. Rumah itu runtuhlah sudah// perbuatan Haji yang "haram zadah"// Haji pun diam tundak 
tengadah// pura-pura tiada ianya endah//. A few swear words came out of the mouth of Si Laba.

Of course, Si Laba got mad because his hut collapsed due to such powerful sex plays, and the anger had to be solved by a male fight. Si Laba pun sangat hatinya geram// mencabut golok lalu menerkam// Haji pun mencabut badik yang tajam// keduanya sama hendak bertikam//. Fortunately, the two women in the hut hurried to break up the two fighting men who had just finished each of their duties as tough scavengers. Bini Si Laba datang berlari// memeluk Si Laba sambil berperi// hendaknya sabar kiranya diri// Haji pun sudah dipeluk isteri.

But, what can they do, the commotion has stirred the whole village. Automatically they become a show in the early hours of the morning. Jadilah gempar sekalian orang// sebab perbuatan Haji yang garang// ada tertawa ada memberang//. There is nothig to say, the disgrace is open. Some laughed, some were angry. In RAH statement, pekerjaan yang sulit jadilah terang//. The "Sulit" diction in Malay means secret. A secret agreement from those who plan the "Cina Buta" marriage was revealed.

As the most importance person, Lebai Guntur also ran and wanted to know what had happened to the play he directed. However, he did not realize that he only wore pants, he also became the center of the villagers laughter Lebai Guntur datang berlari// berseluwar bulat ia berdiri// orang pun tertawa kanan dan kiri// malunya Lebai tidak terperi//. "seluwar bulat" diction are the same as "sempak" or pants in the old fashion model.

\subsection{Shame and Humiliation Due to do "Cina Buta"}

Fadhilat ini sudahlah nyata
sebab pekerjaan bercina buta
mengikutkan hawa nafsu yang meta
jadilah beroleh nama yang lata

Apabila sudah lepas 'iddahnya

Lebai pun balik kepada isterinya

dibaharui nikah oleh walinya

harang terconteng atas mukanya
Apabila sudah siangnya hari

Haji pun bermohon kepada isteri

berpeluk bercium tiada terperi

berpaling ke belakang thalaqnya diberi

In describing disgraceful things, RAH chose regional Malay dialects, as example méta which means not polite. This is the Terengganu Malay dialects (Kamus Dewan, 1992: 825), while the diction lata is classical Malay which means dhaif, hina (Dictionary Dewan, 1992: 717). Apabila sudah siangnya hari// Haji pun bermohon kepada isteri// berpeluk bercium tiada terperi// berpaling ke belakang thalaqnya diberi//. With the talak that Haji Dermawan said to Encik Jurita, the drama of the "Cina Buta" marriage was ended. Apabila sudah lepas 'iddahnya// Lebai pun balik kepada isterinyal/ dibaharui nikah oleh walinyal/ harang terconteng atas mukanyal/. The disgrace was described as black charcoal that tarnished the face of Guntur Lebai.

\subsection{The end of story : Sirih Pulang ke Gagang Tampuk Pulang ke Labu}

Sudah nikah masuk kelambu

di sanalah Lebai memuaskan kalbu keduanya sama bersuka hati

kasih dan sayang beribu kati 
berbagai-bagai madah dan cumbu

kerana hendak mendaki kubu barang yang lepas sudah didapati

cinta mahabbah jadi sebati

Ends the story of this marriage, RAH compare it to sirih pulang ke gagang, tampuk pulang ke labu. "Sirih" and "Labu" are two types of plants that are familiar in Malay culture. "Gagang" and "tampuk" have the same meaning, which is petiole and stalk: the betel stem is the same as the betel stalk, the pumpkin calyx is the same as the pumpkin stalk. This is an old Malay proverb to describe something that returns to its base, back to its habitat. The equivalent of this proverb is bangau pulang ke sarang.

SLG dwells on intercourse, so even at the end of the story, sex is still displayed. This time it is between Lebai Guntur and Encik Jurita. Sudah nikah masuk kelambu// di sanalah Lebai memuaskan kalbu// berbagai-bagai madah dan cumbu// kerana hendak mendaki kubu/l. This time, RAH used diction mendaki kubu as a compound word instead of intercourse. Diction "kubu" means a sturdy fence that is commonly used to protect from enemy attacks (Kamus Dewan, 1992: 666). In conventional war, "mendaki kubu" is not an easy job. It takes courage, skill, and strength because it will surely drain energy and adrenaline. That is how RAH compare the sexual activity with climbing of the stronghold.

The "Cina Buta" play ended as if it is a happy ending, with abundant affection between Lebai Guntur and Encik Jurita as it reads in the last verses. Keduanya sama bersuka hati// kasih dan sayang beribu kati// barang yang lepas sudah didapati// cinta mahabbah jadi sebati//. But truly, disgrace and shame are the end of the story as described by the RAH in the last verse. Habislah qishshah Lebai nan tuan// dengan Jurita muda rupawan// serta dengan Haji Dermawan// menjadi muhallil demikian kelakuan//. Perbuatan Lebai tidak kelulu// memberi thalaq gopoh terlalu// tiada hendak berpikir dahulu// ahkirnya Lebai beroleh malu//.

\section{Conclusions}

SLG is actually RAH allusion to the reality of the marriage of "Cina Buta" or muhllil in the Malay community in the past. This satire is a form of his moral responsibility as a cleric, but because he was also a writer, his allusions were delivered in verse by taking the play of Lebai Guntur and his wife Encik Jurita. Then the choices of erotic diction to tell the stories around sex in "Cina Buta" marriage remain smooth and beautiful without being trapped in vulgar and pornographic sentences.

As the last note, although Lebai Guntur and Encik Jurita have renewed their marriages, the marriage remains invalid because it has been through the fabrication of a forbidden "Cina Buta" marriage. It means the divorce status of the three talak between Lebai Guntur and Encik Jurita did not fall with the artificial muhlil. Surprisingly, because RAH satire usually starts from the "shame" of Malay culture, but it does not involving shara law '. There is no any link between the "Cina Buta" marital behavior with the Prophet's hadith which condemns the practice of muhllil in RAH poem. 


\section{References}

Hasan, M,Y. (1986). Kata-kata daerah dalam karya-karya Shahnon Ahmad. Tanggapan pembicaraan karya-karya Shahnon Ahmad. Kuala Lumpur: Dewan Bahasa dan Pustaka.

Mustari. (2016). Tuntunan Pernikahan dalam Naskah Syair Suluh Pegawai Karya Raja Ali Haji: Kajian Intertekstualitas. Prosiding Seminar Hasil Penelitian Kebahasaan dan Kesastraan. Yogyakarta: Kerjasama antara: Balai Bahasa Daerah Istimewa Yogyakarta; Fakultas Adab dan IImu Budaya Universitas Islam Negeri Sunan Kalijaga Yogyakarta; Pusat Penelitian dan Pengabdian Masyarakat Sekolah Tinggi Multimedia "MMTC"; Fakultas Pendidikan Bahasa dan Seni Universitas Negeri Yogyakarta; Fakultas IImu Budaya Universitas Gadjah Mada.

Mustari. (2018). Syair Lebai Guntur: Kawin "Cina Buta" Karya Raja Ali Haji Dalam Konteks Budaya Melayu Dan Ajaran Islam. Prosiding Seminar Antarabangsa Linguistik Dan Pembudayaan Bahasa Melayu ke-10 (SALPBM X). Malaysia: Jabatan Bahasa Melayu, Fakulti Bahasa Moden dan Komunikasi, Universiti Putra Malaysia dan Dewan Bahasa dan Pustaka.

Mat, N. (2014). Pemikiran penyair Melayu. Selangor: Shah Alam: Karisma Publications.

Saheeh International. (1997). The Qur'an: English Meanings. Jeddah: Abul-Qasim Publishing House.

Shahnon, A. (1979). Gubahan novel. Kuala Lumpur: Dewan Bahasa dan Pustaka.

Sikana, M. (1988). Asas menganalisa sastera. Bandar Baru Bangi: Karyawan.

Rahman, F. (2017). Cyber Literature: A Reader-Writer Interactivity, in International Journal of Social Sciences \& Educational Studies, ISSN 2520-0968 (online). ISSN 2409-1294 (print). June 2017, Vol.3, No 4. 